\title{
Assessment of children's psychomotor development in the remote period after aortic arch reconstruction with antegrade cerebral perfusion
}

\section{Y. P. Truba ${ }^{1}$, L. M. Tkachenko ${ }^{1}$, R. I. Sekelyk ${ }^{2}$, I. V. Dzyurii ${ }^{1}$, V. V. Lazoryshynets ${ }^{1}$}

${ }^{1}$ Amosov National Institute of Cardiovascular Surgery, Kyiv,

${ }^{2}$ Center For Pediatric Cardiology and Cardiac Surgery, Kyiv

\section{Оцінка психомоторного розвитку дітей у віддаленому періоді після пластики дуги аорти в умовах антеградної церебральної перфузіі}

\section{Я. П. Труба ${ }^{1}$, Л. М. Ткаченко ${ }^{1}$, Р. І. Секелик ${ }^{2}$, І. В. Дзюрий ${ }^{1}$ В. В. Лазоришинець ${ }^{1}$}

${ }^{1}$ Національний інститут серцево-судинної хірургії імені М. М. Амосова НАМН України, м. Київ, ${ }^{2}$ Науково-практичний медичний центр дитячої кардіології та кардіохірургії МОЗ України, м. Київ

\begin{abstract}
Objective. To evaluate the psychomotor development of children after aortic arch reconstruction in the conditions of selective antegrade cerebral perfusion.

Materials and methods. The results of surgical treatment and psychomotor development of 48 children aged 1 to 3 years, who underwent reconstruction of the aortic arch in terms of artificial circulation and selective antegrade cerebral perfusion at the age of 1 year at the Amosov National Institute of Cardiovascular Surgery and the Scientific and Practical Medical Center of Pediatric Cardiology and Cardiac Surgery in the period from 2014 to 2019 were analyzed. To study the cognitive sphere and motor development of children we used the $2^{\text {nd }}$ edition of the method "Bayley Scales of Infant Development - II". In analyzing the results in children with psychomotor developmental delay, the values of the mental index and the index of psychomotor development were taken into account.

Results. 2 (3.7\%) patients died after surgery. Postoperative mortality was connected with neurological complications and technique of cerebral perfusion. In the remote period no patient died. According to neurosonography in the postoperative period, no pathological structural changes in the brain were detected. In $16(33.3 \%)$ children at the age of 1 year there was a slight delay in mental and / or psychomotor development. Evaluation of the results of the survey in the dynamics showed that at the age of 3 years, 9 (18.7\%) children had a slight development delay. The average values of the mental index in 1 year were $81.2 \pm 8.6$, and in 3 years $-96.4 \pm 12.7$ $(\mathrm{p}<0.05)$, and the index of psychomotor development - respectively $83.3 \pm 11.4$ and $94.5 \pm 10.2(\mathrm{p}<0.05)$. The difference between the indicators of mental and psychomotor indices in children with congenital heart disease at 1 year and 3 years is statistically significant. Conclusions. A delay in psychomotor development at the age of 1 year was revealed in $33.3 \%$ of children after the aortic arch reconstruction in the conditions of selective antegrade cerebral perfusion. This indicates the need for further research and monitoring. A statistically significant difference between the indicators of mental and psychomotor development of children aged 1 and 3 years after aortic arch reconstruction indicates a positive dynamics and recovery of psychomotor development with age
\end{abstract} in most of children.

Keywords: antegrade cerebral perfusion; psychomotor development; hypoplasia of the aortic arch.

Реферат

Мета. Оцінити психомоторний розвиток дітей після реконструкції дуги аорти в умовах селективної антеградної церебральної перфузії.

Матеріали і методи. Проведено аналіз результатів хірургічного лікування та оцінку психомоторного розвитку 48 дітей віком від 1 до 3 років, яким було виконано реконструкцію дуги аорти в умовах штучного кровообігу і селективної антеградної церебральної перфузії у віці до 1 року в Національному інституті серцево-судинної хірургії імені М. М. Амосова та Науково-практичному медичному центрі дитячої кардіології та кардіохірургії МОЗ України в період з 2014 по 2019 р. Для дослідження когнітивної сфери і моторного розвитку дітей було використано друге видання методики «Шкала розвитку малюків N. Bayley» (Bayley Scales of Infant Development - II). При аналізі результатів у дітей із затримкою психомоторного розвитку до уваги брали значення ментального індексу та індексу психомоторного розвитку.

Результати. Після операції померли 2 (3,7\%) пацієнти. Післяопераційна летальність не була пов’язана з неврологічними ускладненнями та методикою проведення церебральної перфузії. У віддаленому періоді жоден пацієнт не помер. За даними нейросонографії в післяопераційному періоді патологічних структурних змін головного мозку не виявлено. У 16 (33,3\%) дітей у віці 1 року відзначено легку затримку ментального та/або психомоторного розвитку. Оцінка результатів обстеження в динаміці показала, що у віці 3 років легку затримку розвитку мали 9 (18,7\%) дітей. Середні значення ментального індексу в 1 рік становили 81,2 $\pm 8,6$, а в 3 роки - 96,4 $\pm 12,7$ ( $<<0,05)$, а індекс психомоторного розвитку - відповідно 83,3 \pm $11,4$ i 94,5 $\pm 10,2$ ( $<<0,05)$. Різниця між показниками ментального та психомоторного індексів у дітей із вродженими вадами серця в 1 рік та 3 роки статистично значуща.

Висновки. У 33,3\% дітей після реконструкції дуги аорти в умовах селективної антеградної церебральної перфузії виявлена затримка психомоторного розвитку у віці 1 року. Це вказує на необхідність подальшого дослідження та спостереження Статистично значуща різниця між показниками ментального та психомоторного розвитку дітей у віці 1 та 3 років після реконструкції дуги аорти свідчить про позитивну динаміку та відновлення психомоторного розвитку з віком у більшості дітей.

ключові слова: антеградна церебральна перфузія; психомоторний розвиток; гіпоплазія дуги аорти. 
Surgical intervention for the aortic arch reconstruction in newborns and infants involves the resolution of several issues, which depend on its fundamentally different methods. First, it is a matter of choice of the operative access: sternotomy or thoracotomy, which in turn is determined by the need to use artificial circulation (AC). Secondly, when correcting defects in the AC condition, it is necessary to determine the brain protection method: selective cerebral perfusion or deep hypothermic circulatory arrest. Currently, there is no consensus in favor of a particular method for the brain protection during reconstructive surgery on the aortic arch. There are many retrospective studies, showing the advantage of cerebral perfusion over deep hypothermia with $\mathrm{AC}$ arrest. However, according to modern prospective randomized studies, there is no difference in the development of neurological complications between the two methods [1, 2]. In recent years, most leading cardiac surgery clinics have preferred the use of antegrade selective cerebral perfusion.

The number of children operated on the aortic arch is constantly increasing, and regardless of the method of brain protection during surgery selected, the doctors and the parents are faced with the question of how children would develop in the future after such operations. That is why, the assessment of psychomotor development in children with congenital heart disease (CHD) in the post-operation period is gradually becoming part of everyday practice not only to identify those with impaired neurological and psychomotor development, but to identify the risk factors and develop psychosocial care strategies as well.

During the correction of complex problems in the adequate cerebral blood supply, hypoxia, and even more so a cerebral ischemia can adversely affect the further psycho-neurological development of a child. According to the literature, about $25 \%$ of children with VVS have neurological dysfunctions in the long term, which are manifested by learning problems, impaired attention, hyperactivity, emotional disorders, difficulty in mnestic processes [3]. That is why, the children who underwent cardiac surgery for the BBC correction, especially in the conditions of $\mathrm{AC}$, need a constant monitoring and assessment of psychomotor development [4].

In newborns and infants in the early post-operative period, it is important to assess the degree of hypoxic damage and its impact on the long-term psycho-neurological development of a child. Bailey Child Development Scales are most widely used to assess the development of children from birth to three years of age. The first version of this technique was published in 1969 and was named "Bayley Scales of Infant Development - BSID". The scales were then revised, standardized, and published in 1993, as a second edition (BSIDII). Despite criticism of the methodology due to complexity of the assessment procedure by users, the Bailey scales have become the most anticipated tool for the children's development assessment. In 2006, they were re-standardized. Thus, the third edition of the scales have appeared the Bayley Scales of Infant and Toddler Development, Third edition (Bayley-III) [5].
The purpose of the study: to assess the level of psychomotor development in the children, who underwent the aortic arch reconstruction in the conditions of selective antegrade cerebral perfusion.

\section{Materials and methods}

The study was based on the analysis of the surgical treatment results and psychomotor development of 48 children, aged from 1 to 3 years, who have in the neonatal period undergone the aortic arch reconstruction in conditions of $\mathrm{AC}$ and selective antegrade cerebral perfusion at the Amosov National Institute of Cardiovascular Surgery and the Scientific and Practical Medical Center for Pediatric Cardiology and Cardiac Surgery in the period from 2014 to 2019. There were 14 girls (29.1\%) and 34 boys (70.9\%). The average age of the patients at the time of surgery was $(1.5 \pm 0.4)$ months, and the average body weight $-(3.9 \pm 1.3) \mathrm{kg}$. A total of 54 patients underwent a cerebral perfusion surgery during this period, but 2 patients died in the early post-operation period and contact was lost with 4 patients in the long term. Neurosonography was performed to assess the condition of the central nervous system before surgery and in post-operative period. Diagnosis of the BBC and assessment of the anatomy of the aortic arch was performed, using echocardiographic (echocardiography) examination. In most patients of the study group (96.8\%) hypoplasia of the aortic arch was combined with other BBC (Table 1). Operations were performed through median sternotomy under AC and selective antegrade cerebral perfusion with moderate hypothermia (patients were cooled to $24-26^{\circ} \mathrm{C}$ ). The technique of antegrade selective perfusion of the brain in the correction of hypoplasia of the aortic arch in newborns and infants involves a number of consecutive actions. Prior to surgery, catheterization of the right radial and one of the femoral arteries was performed to monitor the blood pressure (BP) invasively. Two sensors for monitoring of cerebral oxygenation $\left(\mathrm{SatO}_{2}\right.$ ) were placed on the patient's forehead on both sides and the results were displayed on the monitor. Cerebral oxygen saturation was measured, using the Somenetics INVOS machine. This sensor emits waves with a length of $730-810 \mathrm{~nm}$, providing constant monitoring of regional oxygen saturation of hemoglobin in the cerebral cortex. After median sternotomy and pericardial incision done, the ascending aorta, aortic arch, brachiocephalic vessels, and part of the descending aorta were mobilized. After heparin administration, the ascending aorta was cannulated with a flexible reinforced aortic cannula of a standard diameter without a limiter. The AC device was connected, according to the "aorta-vena cava" scheme. The levels of hematocrit, potassium, and acid-base status of the blood were monitored constantly. During the direct reconstruction of the aortic arch, the arterial cannula was shifted into the brachiocephalic trunk, clamping other vessels of the aortic arch, and antegrade selective cerebral perfusion was initiated. The volumetric rate of $\mathrm{AC}$ was reduced to 50-60 ml / kg / min, what have constituted approximately 
Table 1. Concomitant CHD in the correction of the aortic arch in the conditions of cerebral perfusion

\begin{tabular}{|l|c|c|}
\hline \multicolumn{1}{|c|}{ CHD } & \multicolumn{2}{c|}{ Number of patients } \\
\cline { 2 - 3 } & \multicolumn{2}{c|}{$\mathrm{n}$} \\
\hline Transposition of main arteries & 18 & 33,3 \\
\hline Ventricular septal defect & 19 & 35,2 \\
\hline Atrial septal defect & 5 & 9,2 \\
\hline Atrioventricular septal defect & 4 & 7,4 \\
\hline Aortic stenosis & 3 & 5,5 \\
\hline Total abnormal drainage of the pulmonary veins & 1 & 1,9 \\
\hline Double departure of the main vessels from the right ventricle & 1 & 1,9 \\
\hline Abnormal departure of the left coronary artery from the pulmonary artery & 1 & 1,9 \\
\hline Isolated form & 2 & 3,7 \\
\hline Total ... & 54 & 100 \\
\hline
\end{tabular}

\section{Table $2 . \quad$ Average values of perioperative indicators}

\begin{tabular}{|l|c|}
\hline \multicolumn{1}{|c|}{ Indicator } & Average value ( \pm SD) \\
\hline Duration & $268,5 \pm 83,6$ \\
\hline operations, min & $131,4 \pm 46,4$ \\
\hline artificial circulation, min & $86,1 \pm 34,2$ \\
\hline aortic compression, min & $19,5 \pm 6,1$ \\
\hline selective antegrade cerebral perfusion, min & $25,7 \pm 3,4$ \\
\hline The cooling temperature of the patient during cerebral perfusion, ${ }^{\circ} \mathrm{C}$ & \\
\hline
\end{tabular}

$30 \%$ of the calculated rate. The mean blood pressure in the right radial artery was maintained in the range of $50-55$ $\mathrm{mm} \mathrm{Hg}$. Art. After the main stage of the operation, the aortic cannula was moved into the lumen of the aortic arch, the volumetric perfusion rate was increased to the calculated one, and the patient was warmed. After achieving normothermia, and normalization of cardiac activity, the AC was gradually stopped.

The BSID-II method was used to study the cognitive sphere and motor development of the children. The values of the Mental Development Index (MDI) and the Psychomotor Development Index (PDI) of 84 points and below were taken into account, when analyzing the results in children with the psychomotor developmental delay. The number of points 85 - 114 was considered the average age norm, and 115 points and above - an advance in development. The study was conducted twice: for the first time at the age of 1 year, and for the second time - at the age of 3 years. The child was offered tasks with various toys in the form of a game. Assessment of psychomotor development was performed by a child psychologist and lasted from 30 to 90 minutes.

The study results were processed, using the IBM SPSS Statistics for Mac, Version 26.0 software. Continuous variables were expressed as means \pm standard deviation. Student's ttest was used to compare values. The values of $\mathrm{p} \leq 0.05$ were estimated as statistically significant.

\section{Results}

Two (3.7\%) patients died after surgery. Postoperative mortality was not associated with neurological complications or cerebral perfusion. In the long-term period, no one patient died. Due to loss of contact with some patients from the Crimea and the temporarily occupied territories of Donetsk and Luhansk oblasts, a psychomotor development was assessed in 48 patients only.

As we see from the Table 2, the AC duration and of the ischemia during aortic clamping were standard for operations to correct the complex heart failures. Regarding the duration of selective antegrade cerebral perfusion, i.e. the duration of reconstruction of the aortic arch, it have corresponded to the average duration of plastic surgery on the aortic arch from the lateral access.

Indicators of the venous blood saturation of the frontal area during preparation for the main stage of the operation were within normal limits - $(67 \pm 2.3) \%$. The blood pressure was maintained at $(63 \pm 4.5) \mathrm{mm} \mathrm{Hg}$. Art. Normocapnia was maintained, no signs of the tissue hypoperfusion were observed (the venous blood lactate concentration remained at up to $2 \mathrm{mmol} / \mathrm{l}$ ). During the main stage of the operation, the venous blood saturation in the frontal area of the skin have remained at the level of $(57 \pm 3.2) \%$, what indicated the effectiveness of antegrade cerebral perfusion. The duration of antegrade perfusion of the brain have averaged (19.6 \pm 7.2) minutes. After completion of the main stage of the operation, restoration of cardiac activity, warming of the patient to normothermia and after cessation of AC, the indicators of the venous blood saturation in frontal lobe of the brain (Table 3) have remained at a baseline level- (68 \pm 3.2$) \%$.

According to postoperative data of neurosonography, pathological structural changes in the brain were not detected. In the early post-operation period, tonic-clonic sei- 
Table 3. Indicators of cerebral oximetry and blood pressure during aortic arch reconstruction

\begin{tabular}{|l|c|c|c|c|c|}
\hline \multirow{2}{*}{\multicolumn{1}{|c|}{ Indicator }} & \multicolumn{5}{|c|}{ The value of the indicator at different stages of the operation } \\
\cline { 2 - 6 } & initial data & beginning of AC & antegrade perfusion & AC stop & end of operation \\
\hline $\mathrm{SatO}_{2}, \%$ & $67 \pm 2,3$ & $61 \pm 2,1$ & $57 \pm 3,2$ & $59 \pm 5,7$ & $68 \pm 3,2$ \\
\hline $\mathrm{BP}, \mathrm{Hg}$ & $63 \pm 4,5$ & $52 \pm 6,3$ & $48 \pm 4,2$ & $62 \pm 2,5$ & $67 \pm 3,6$ \\
\hline
\end{tabular}

Table 4. MDI and PDI in children $(n=48)$ after aortic arch reconstruction

\begin{tabular}{|l|c|c|}
\hline \multirow{2}{*}{\multicolumn{1}{|c|}{ Study groups }} & \multicolumn{2}{c|}{ Average values of indicators } \\
\cline { 2 - 3 } & MDI & $83,3 \pm 11,4$ \\
\hline At the age of 1 year & $81,2 \pm 8,6$ & $94,5 \pm 10,2$ \\
\hline At the age of 3 years & $96,4 \pm 12,7$ & PDI \\
\hline
\end{tabular}

zures were observed in 4 (6.2\%) patients, whose drug treatment was successful.

For evaluation of the mental and psychomotor development in the children they were called for routine postoperative examination. Psycho-diagnostics of mental and psychomotor development was performed by a pediatric psychologist of the department. The study results are presented in Table 4.

At the first stage of the study, the average values MDI and PDI in children aged 1 year were analyzed. For 16 (33.3\%) children at the age of 1 year there was a slight delay in mental and/or psychomotor development. For the remaining 32 (66.7\%) children, the average number of indices was within the age norm (see figure).

In the second stage of the study, the data of mental and psychomotor development of both, children with normal indicators and children with psychomotor developmental delays after the first examination, were analyzed.

The evaluation of the survey results in the dynamics have shown, that at the age of 3 years, 9 (18.7\%) children had a slight developmental delay. The average values MDI in children at the age of 1 year were $81.2 \pm 8.6$, and at the age of 3 years $-96.4 \pm 12.7(\mathrm{p}<0.05)$; PDI - respectively, $83.3 \pm 11.4$ and $94.5 \pm 10.2(\mathrm{p}<0.05)$.

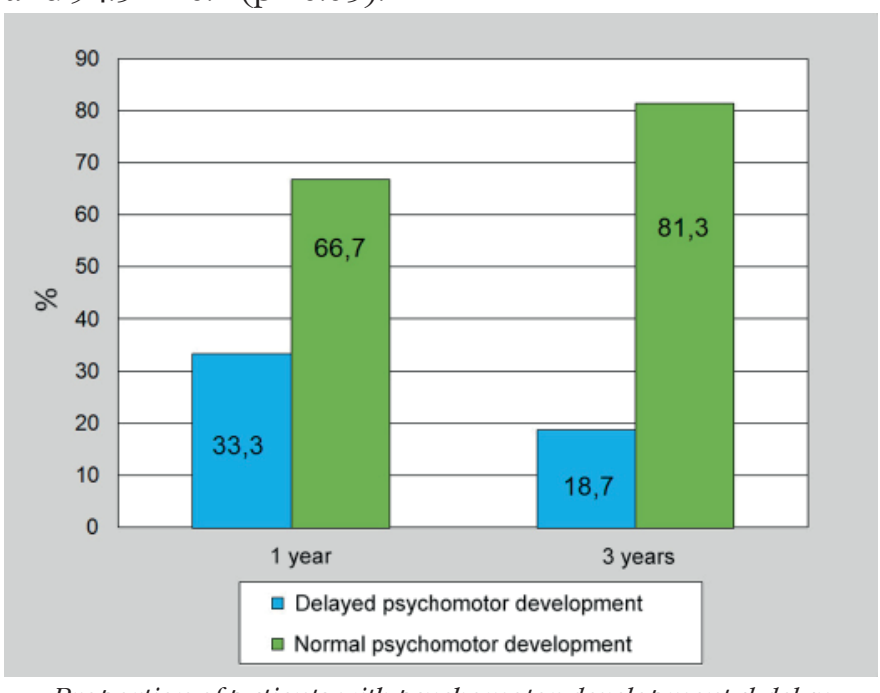

Proportion of patients with psychomotor developmental delay at the age of 1 year and 3 years.
Thus, a statistically significant difference was found between the indicators of mental and psychomotor development in children aged 1 year and 3 years after reconstruction of the aortic arch, what indicates a positive dynamics and a significant leveling of developmental delays with age for most children. However, all the children, who underwent the aortic arch reconstruction in the conditions of $\mathrm{AC}$ and cerebral perfusion need further psychophysical examination in a preschool and school age.

\section{Discussion}

With the development of pediatric cardiac surgery, the number of patients for whom surgery for hypoplasia of the aortic arch has been successful is constantly increasing. Despite the rapid progress of cardiac surgery, the risk of damage and disturbance of the brain development in newborns and infants remains high. However, in newborns it is difficult to assess the degree of hypoxic damage and its impact on the long-term neurological development of a child.

Surgery for aortic arch hypoplasia in many patients involves the use of AC. This applies to interventions for hypoplasia of the proximal aortic arch, hypoplasia of the entire aortic arch or simultaneous correction of concomitant airways and the aortic arch plasticity. Directly the stage of reconstruction of the aortic arch can be performed either by completely stopping of the AC, meaning in the conditions of circulatory arrest or by performing of antegrade cerebral perfusion. An important issue is the temperature, at which surgical correction is performed. Traditionally, circulatory arrest in conditions of deep hypothermia has been associated with negative neurological results [6]. An important point is the duration of a complete arrest of AC. It is after a prolonged circulatory arrest, when the brain damage is observed. In multicenter studies, its duration of $41 \mathrm{~min}-$ utes was determined to be safe in terms of the development of neurological complications [7]. The introduction of antegrade cerebral perfusion in clinical practice has provided an alternative to circulatory arrest [8]. During antegrade cerebral perfusion, selective blood flow to the brain is selectively supplied during the critical period of aortic arch reconstruction, reducing the risk of neurological and cognitive deficits after surgery. Since then, scientific publica- 
tions have reported comparative data from these two techniques, concerning the brain damage and development of neurological symptoms. Many cardiac surgery centers have shown fewer cerebral lesions according to Magnetic Resonance Imaging, proving the benefits of antegrade cerebral perfusion over circulatory arrest [9]. At the same time, randomized studies have not shown a statistically significant difference in the observance of neurological complications between the two methods [10]. Experience has shown that both methods of the vital organs protection during aortic arch surgery in infants are associated with risk of damage to the central nervous system.

An important aspect of the operations on the aortic arch performance is the monitoring of cerebral oximetry. This non-invasive and simple method is used both during operations and in post-operative period in intensive care units, what avoids more invasive monitoring methods. Recently, real-time measurement of hemoglobin oxygenation of cerebral tissue, using infrared spectroscopy, is widely used in cardiac surgery. Detection of low cerebral oxygenation during the aortic arch reconstruction in infants, as well as related physiological factors, such as hypotension and hypoxemia, improves the safety of anesthesia, as these mechanisms can be prevented by anesthesiologist to avoid the damage to central nervous system [11]. However, there is currently insufficient clinical data on critical levels of the measurements, which are necessary for the safe management of perioperative period.

There are many risk factors for cognitive impairment. The presence of $\mathrm{BBC}$, even before complex surgical correction, already affects the development of central nervous system [12]. During correction of complex BBC, it is the level of hypothermia and blood flow during $\mathrm{AC}$, which impact the neurological morbidity occurrence.

We prefer to perform the aortic arch reconstruction (AAR) for infants with concomitant heart defects in conditions of $\mathrm{AC}$, moderate hypothermia, and with application of antegrade selective cerebral perfusion for the brain protection. In our study, the mortality due to the use of cerebral perfusion or inadequate temperature was absent, because the deceased patients had no neurological symptoms. According to the results of examination of the patients in a longterm period, no neurological disorders or restoration of psychomotor development in case of its delay were observed.

\section{Conclusions}

In $33.3 \%$ of children after reconstruction of the aortal arch in the conditions of selective antegrade cerebral perfusion, a psychomotor development delay at the age of 1 year old occurs. This indicates a need for further research and monitoring. The BSID-II Infant Development Scale is effective for assessing of psychomotor development in children after surgical correction of the aortal arch hypoplasia and can be used to study the mental and psychomotor development in them. A statistically significant difference between the indicators of mental and psychomotor development of children aged 1 year and 3 years after reconstruction of the aortal arch indicates a positive dynamics and recovery of psychomotor development with ageing for most of them.

Financing. The study was conducted in the framework of research funding: "Organize a system of emergency and urgent cardiac surgery for patients with critical congenital heart disease" of the Amosov National Institute of Cardiovascular Surgery.

Contribution of each participant. Truba Ya.P. - developing a strategy for patient management, performing surgical interventions, concept and design of the research, analysing the results and statistical data processing, preparing all sections of the article; Tkachenko L.M. - conducting psychodiagnostics of mental and psychomotor development of children during a routine examination, creating a database; Sekelyk R.I. - developing a strategy for patient management, performing surgical interventions, creating a database; Dzyury I.V. - assistance in operations, surgical manipulations during the post-operation period, analysis of results and statistical data processing, participation in the preparation of all sections of the article; Lazoryshynets V.V. - concept and design of the research, developing a strategy for treatment of patients, performing operative interventions, analysing the results and statistically processing the data, preparing all sections of the article.

Conflict of interest. The authors state that there are no potential conflicts of interest

\section{References}

1. Algra SO, Jansen NJ, van der Tweel I, Schouten AN, Groenendaal F, Toet M, et al. Neurological injury after neonatal cardiac surgery: a randomized, controlled trial of 2 perfusion techniques. Circulation. 2014 Jan 14;129(2):224-33. doi: 10.1161/CIRCULATIONAHA.113.003312. Epub 2013 Oct 20. PMID: 24141323.

2. Kornilov IA, Sinelnikov YS, Soinov IA, Ponomarev DN, Kshanovskaya MS, Krivoshapkina AA, et al. Outcomes after aortic arch reconstruction for infants: deep hypothermic circulatory arrest versus moderate hypothermia with selective antegrade cerebral perfusion. Eur J Cardiothorac Surg. 2015 Sep;48(3):e45-50. doi: 10.1093/ ejcts/ezv235. Epub 2015 Jul 3. PMID: 26141543.

3. Donofrio MT, Duplessis AJ, Limperopoulos C. Impact of congenital heart disease on fetal brain development and injury. Curr Opin Pediatr. 2011 Oct;23(5):502-11. doi: 10.1097/MOP.0b013e32834aa583. PMID: 21881507.

4. Uzark K, Smith C, Donohue J, Yu S, Romano JC. Infant Motor Skills After a Cardiac Operation: The Need for Developmental Monitoring and Care. Ann Thorac Surg. 2017 Aug; 104(2):681-6. doi: 10.1016/j. athoracsur.2016.12.032. Epub 2017 Mar 24. PMID: 28347538.

5. Anderson PJ, Burnett A. Assessing developmental delay in early childhood - concerns with the Bayley-III scales. Clin Neuropsychol. 2017 Feb;31(2):371-81. doi: 10.1080/13854046.2016.1216518. Epub 2016 Aug 12. PMID: 27687612.

6. Bellinger DC, Wypij D, Kuban KC, Rappaport LA, Hickey PR, Wernovsky $\mathrm{G}$, et al. Developmental and neurological status of children at 4 years of age after heart surgery with hypothermic circulatory 


\section{Киінічна хірургія}

\section{Klinichna khirurhifa}

arrest or low-flow cardiopulmonary bypass. Circulation. 1999 Aug 3;100(5):526-32. doi: 10.1161/01.cir.100.5.526. PMID: 10430767.

7. Wypij D, Newburger JW, Rappaport LA, duPlessis AJ, Jonas RA, Wernovsky G, et al. The effect of duration of deep hypothermic circulatory arrest in infant heart surgery on late neurodevelopment: the Boston Circulatory Arrest Trial. J Thorac Cardiovasc Surg. 2003 Nov;126(5):1397-403. doi: 10.1016/s0022-5223(03)00940-1. PMID: 14666011.

8. Asou T, Kado H, Imoto Y, Shiokawa Y, Tominaga R, Kawachi Y, et al. Selective cerebral perfusion technique during aortic arch repair in neonates. Ann Thorac Surg. 1996 May;61(5):1546-8. doi: 10.1016/0003-4975(96)80002-S. PMID: 8633985.

9. Bhalala US, Appachi E, Mumtaz MA. Neurologic Injury Associated with Rewarming from Hypothermia: Is Mild Hypothermia on Bypass Better than Deep Hypothermic Circulatory Arrest? Front Pediatr. 2016 Sep 28;4:104. doi: 10.3389/fped.2016.00104. PMID: 27734011 ; PMCID: PMC5039167.

10. Goldberg CS, Bove EL, Devaney EJ, Mollen E, Schwartz E, Tindall S, et al. A randomized clinical trial of regional cerebral perfusion versus deep hypothermic circulatory arrest: outcomes for infants with functional single ventricle. J Thorac Cardiovasc Surg. 2007 Apr;133(4):880-7. doi: 10.1016/j.jtcvs.2006.11.029. Epub 2007 Feb 22. PMID: 17382619.
11. Yoshitani K, Kawaguchi M, Ishida K, Maekawa K, Miyawaki H, Tanaka S, et al. Guidelines for the use of cerebral oximetry by nearinfrared spectroscopy in cardiovascular anesthesia: a report by the cerebrospinal Division of the Academic Committee of the Japanese Society of Cardiovascular Anesthesiologists (JSCVA). J Anesth. 2019 Apr;33(2):167-96. doi: 10.1007/s00540-019-02610-y. Epub 2019 Feb 8. PMID: 30737572.

12. Bonthrone AF, Chew A, Kelly CJ, Almedom L, Simpson J, Victor $\mathrm{S}$, et al. Cognitive function in toddlers with congenital heart disease: The impact of a stimulating home environment. Infancy. 2021 Jan;26(1):184-99. doi: 10.1111/infa.12376. Epub 2020 Nov 19. PMID: 33210418 ; PMCID: PMC7894304.

Received: 30.12 .2020 